\title{
Outstanding Enhancement in the Axial Coordination Ability of the Highly Rigid Cofacial Cyclic Metalloporphyrin Dimer
}

\author{
Ken-ichi Yamashita, ${ }^{*}$ Kazuhiro Furutani and Takuji Ogawa \\ [a] Dr. K. Yamashita, K. Furutani, Prof. Dr. T. Ogawa \\ Department of Chemistry, Graduate School of Science \\ Osaka University \\ 1-1 Machikaneyama, Toyonaka, Osaka 560-0043, Japan \\ E-mail: yamashita-k@chem.sci.osaka-u.ac.jp \\ Supporting information for this article is given via a link at the end of the document.
}

\begin{abstract}
Copper- and nickel-porphyrin complexes show extremely weak axial coordination ability without any electron-withdrawing groups. Herein, we report axial ligation on $\mathrm{Cu}^{\prime \prime}$ - and Ni"-porphyrins in a highly rigid cofacial porphyrin dimer with a bidentate ligand, 1,4diazabicyclo[2.2.2]octane (DABCO). To the best of our knowledge, this is the first report on the use of $\mathrm{Cu}^{\prime \prime}$ - and $\mathrm{Ni}^{\mathrm{I}}$-porphyrins for coordination-induced guest binding of porphyrin-based host molecules without the help of other metal ions. The high rigidity of the dimer induces guest binding through the cooperative effect of weak axial ligation. The results showed that $\mathrm{Cu}^{\prime \prime}$ - and $\mathrm{Zn}^{\prime \prime}$-complexes bind one DABCO molecule inside their cavities, whereas the $\mathrm{Ni}$ "-complex binds two additional DABCO molecules outside to form a stable 6coordinate paramagnetic $\mathrm{Ni}^{\prime \prime}$-complexes. The binding constants were determined by the UV/vis titration experiments.
\end{abstract}

\section{Introduction}

The coordination of ligands to a porphyrin central metal is important for many biological reactions, catalysis, and supramolecular chemistry. ${ }^{[1]}$ In porphyrin supramolecular chemistry, axial coordination is responsible for including a guest molecule into the cavity of (multi)porphyrin-based host molecules. ${ }^{[2,3]}$ In addition, large and discrete multimetalloporphyrin macrocycles or cages have been fabricated by template synthesis, which involves the preorganization of porphyrin monomers by axial coordination of well-designed multidentate ligands. ${ }^{[2,4-10]}$

The coordination ability and the maximum coordination number chiefly depend on the metal ion. ${ }^{[1,11,12]}$ For example, zinc porphyrins exhibit a high axial coordination ability to oxygen- and nitrogen-based ligands and readily form a five-coordinate complex. ${ }^{[11]}$ Similarly, magnesium and cobalt porphyrins also exhibit a high axial coordination ability. These metals are commonly used for designing porphyrin-based host molecules that can bind guest molecules through axial coordination. Compared to these metalloporphyrins, nickel and copper porphyrins exhibit a weaker coordination ability with small binding constants $\left(K_{1}=1.08 \mathrm{M}^{-1}, K_{2}=3.79 \mathrm{M}^{-1}\right.$ for $\mathrm{Ni}^{\prime \prime}(\mathrm{tpp})$ (tpp = tetraphenylporphyrinato dianion) with two pyrrolidine ligands, ${ }^{[11,13]}$ and $K_{1}=0.05 \mathrm{M}^{-1}$ for $\mathrm{Cu}$ (t)p) with one pyridine ligand). ${ }^{[1,14-17]}$ Therefore, typical $\mathrm{Cu}^{\prime \prime}$ - and $\mathrm{Ni}^{\prime \prime}$-porphyrins do not exhibit axial coordination in the presence of slight excess of an axial ligand.

A conventional strategy for enhancing the axial coordination ability of these metal ions is to increase their Lewis acidity by introducing electron-withdrawing substituents on the periphery of the porphyrin. ${ }^{[13,18-26]}$ For example, the nickel tetrakis(pentafluorophenyl)porphyrin complex readily accepts two axial ligands to form paramagnetic 6 -coordinate complexes $\left(K_{1}=\right.$ $\left.8.2 \mathrm{M}^{-1}, K_{2}=22.4 \mathrm{M}^{-1}\right)$. ${ }^{[22]}$ Analogous highly electron-deficient tetrapyrrole ligands have been also reported. [27-32]

The cooperative effect of multiple metal ions is also expected to efficiently induce axial coordination. In general, the cooperative binding of a suitable combination of a porphyrin host and a guest ligand is entropically more favorable than that of the corresponding monomer. In particular, structurally rigid multiporphyrin hosts in which the porphyrin units are strongly fixed exhibit significantly higher binding constants for guest molecules of the appropriate size. ${ }^{[2-4,7-9]}$ However, to date, the cooperative effect has not been used to induce axial coordination in metalloporphyrins with a weak binding ability (e.g., $\mathrm{Ni}^{\mathrm{II}}$ and $\mathrm{Cu}^{\prime \prime}$ ), except for one recent report by Anderson et al. ${ }^{[17,33]}$ They reported axial ligation on copper porphyrins without any electronwithdrawing substituents in the heterometallic $\left(\mathrm{Cu}^{\prime \prime} / \mathrm{Zn}^{\prime \prime}\right)$ cyclic porphyrin oligomers with a radial oligopyridyl ligand. This unusual ligation on $\mathrm{Cu}^{\prime \prime}$ porphyrin units induced a cooperative strong ligation on Zn porphyrin units. To the best of our knowledge, there are no reports on guest inclusion by only axial ligation on $\mathrm{Ni}^{\text {Il }}$ or Cull porphyrin units.

In this study, we investigate axial ligation on $\mathrm{Ni}^{\prime \prime}$ and $\mathrm{Cu}^{\prime \prime}$ porphyrins in a highly rigid cofacial porphyrin dimer ${ }^{[3]}$ with a bidentate ligand without using electron-withdrawing substituents or strongly coordinating metal ions such as $\mathrm{Zn}$ " porphyrins. (Figure 1). We have earlier reported the efficient synthesis of a cofacial porphyrin dimer bridged by two 2,7-naththyleneoxylinkers $(\mathbf{1})^{[34]}$ via catalyst-free nucleophilic aromatic substitution reactions. ${ }^{[35-38][39-47]}$ This dimer has a highly rigid structure, as revealed by the diffraction and spectroscopic studies, and has an internal cavity surrounded by two porphyrin moieties with an interplanar distance of $7.5 \AA$, which is suitable for binding a 1,4diazabicyclo[2.2.2]octane (DABCO) molecule. Therefore, we anticipated that the high rigidity of $\mathbf{1}$ can realize axial coordination of DABCO on the metal complexes ( $\mathrm{M}=\mathrm{Zn}^{\prime \prime}, \mathrm{Cu}^{\prime \prime}$, and $\left.\mathrm{Ni}^{\prime \prime}\right)$ of $\mathbf{1}$. In fact, we were able to achieve the inclusion of DABCO in $\mathrm{Cu}^{\text {"l-1 }}$ and $\mathrm{Ni}^{\mathrm{II}} \mathbf{- 1}$. 

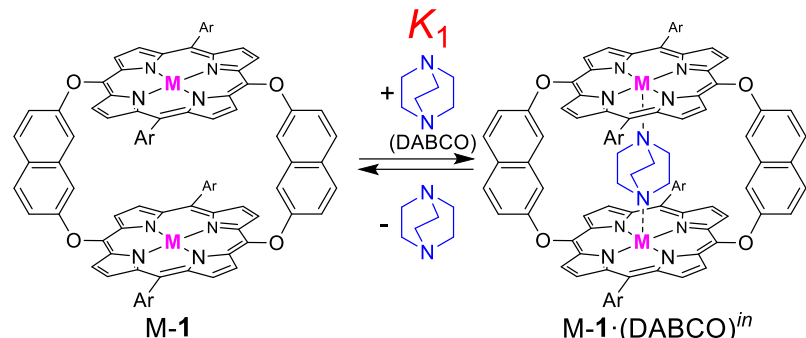

$\mathrm{M}=\mathrm{Zn}, \mathrm{Cu}$, and $\mathrm{Ni}$ $\mathrm{Ar}=3,5$-bis(3-methylbutoxy)phenyl

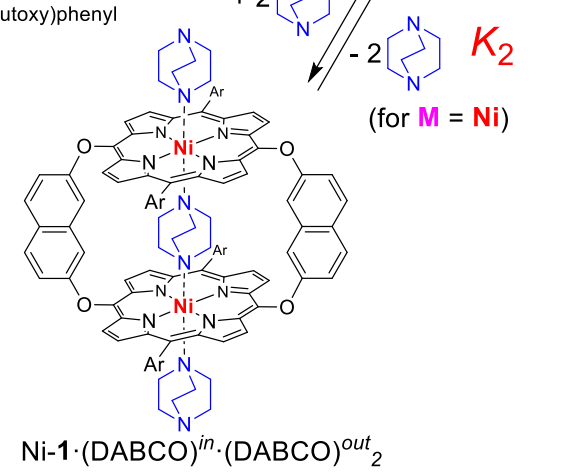

Scheme 1. Axial-coordination-driven inclusion of DABCO into M-1.

\section{Results and Discussion}

First, we evaluated the guest binding behavior of $Z n^{\prime \prime}-1$ with DABCO. As expected, when DABCO is added in a solution of $\mathrm{Zn}^{\prime \prime}$ 1, the DABCO molecules were quickly bound in $\mathrm{Zn}^{\mathrm{I}}-\mathbf{1}$ to form $\mathrm{Zn}$ "1.(DABCO $)^{\text {in }} \cdot \mathrm{Zn}^{\text {"l}}-\mathbf{1} \cdot(\mathrm{DABCO})^{\text {in }}$ exhibited extraordinary stability even on silica gel. Thin-layer chromatography (TLC, hexane/toluene 1:3) analyses showed that $\mathrm{Zn}^{\mathrm{I}}-\mathbf{1} \cdot(\mathrm{DABCO})^{\text {in }}\left(R_{f}=\right.$ $0.9)$ has a different spot from that of unbound $\mathrm{Zn}^{\mathrm{I}}-\mathbf{1}\left(R_{f}=0.4\right)$. Moreover, 2D TLC analyses indicated that the amount of unbound $\mathrm{Zn}^{\text {"l-1 }}$ was mostly negligible (Figure S9). Therefore, Zn" 1.(DABCO) in can be purified by both the typical column chromatography and recrystallization techniques..$^{[9,48]}$

The ${ }^{1} \mathrm{H}$ NMR spectra of purified $\mathrm{Zn}^{11}-\mathbf{1} \cdot(\mathrm{DABCO})^{\text {in }}$ in $\mathrm{CDCl}_{3}$ showed a sharp singlet proton signal for the bound $\mathrm{DABCO}$ molecule at $-4.3 \mathrm{ppm}$, which are significantly upfield-shifted compared to that of free DABCO because of the magnetic shielding by two aromatic porphyrin macrocycles. When both $Z n^{\prime \prime}-$ 1 and $Z n^{11}-\mathbf{1} \cdot(D A B C O)^{\text {in }}$ exist in the solution, their ${ }^{1} \mathrm{H}$ NMR signals were independently observed without any shifts and broadening (Figure S10). Moreover, any change in the ${ }^{1} \mathrm{H}$ NMR spectra of $\mathrm{Zn}^{\prime \prime}-1 \cdot(\mathrm{DABCO})^{\text {in }}$ was mostly negligible even in the presence of guest molecules, and both bound and excess free DABCO peaks were independently observed (Figure S10). These results indicate that the binding and release of DABCO has a slower timescale at room temperature than the NMR timescale. The results also show the high thermodynamic and kinetic stability of $\mathrm{Zn}^{\mathrm{N}}-\mathbf{1} \cdot(\mathrm{DABCO})^{\text {in }}$. Notably, the overall $D_{2 \mathrm{~h}}$ symmetry of $\mathrm{Zn} " \mathrm{l}-\mathbf{1}$ is retained even after the binding of $\mathrm{DABCO}$ with $D_{3 \mathrm{~h}}$ symmetry. This phenomenon indicates fast rotation of the $D A B C O$ molecule along the $Z n^{\prime \prime}-N \cdots N-Z n$ " axis inside the cavity of $Z n^{\prime \prime}-1$, which is typical of the reported DABCO-coordinated $\mathrm{Zn}^{\mathrm{II}}$-porphyrin hosts. ${ }^{[48-54]}$
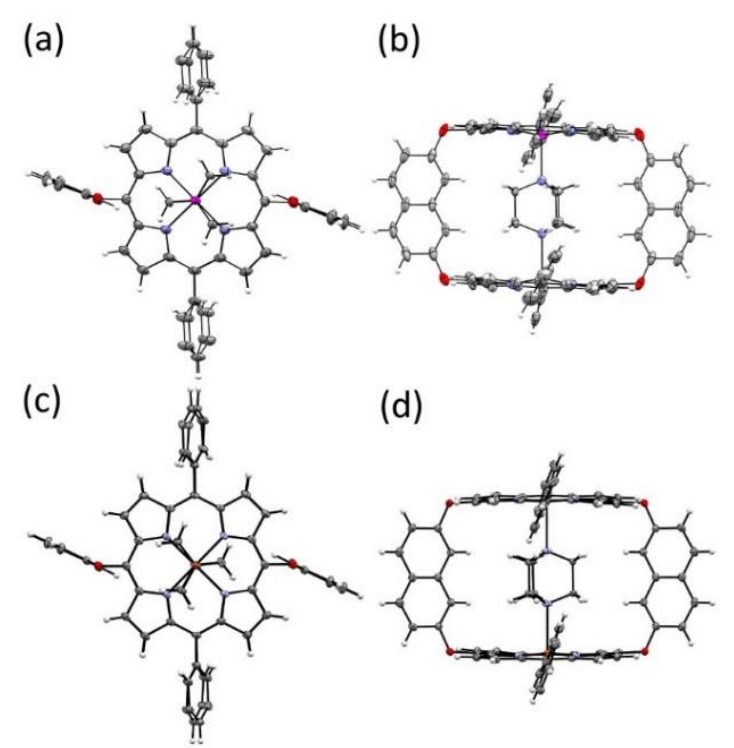

(d)

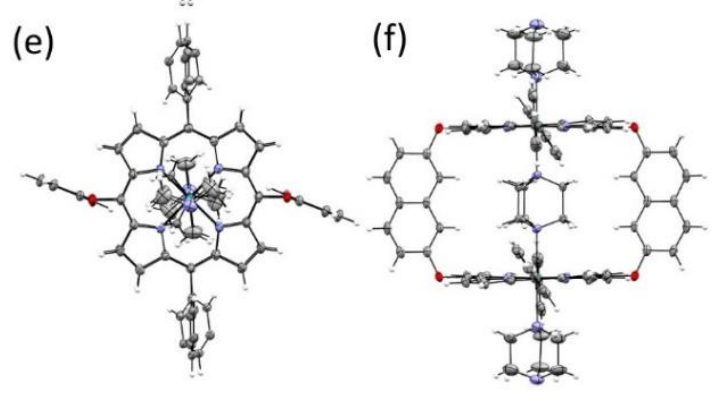

Figure 1. Thermal ellipsoid representations (40\% probability level) of the crystal structure of M-1.(DABCO) in . (a) Top and (b) side views of $\mathrm{Zn}^{\mathrm{l}}-\mathbf{1} \cdot(\mathrm{DABCO})^{\text {in }}$, (c) top and (d) side views of $\mathrm{Cu}^{\mathrm{ll}}-\mathbf{1} \cdot(\mathrm{DABCO})^{\text {in }}$, and $(\mathrm{e})$ top and $(\mathrm{f})$ side views for the crystal structure of $\mathrm{Nill}^{\mathrm{ll}} \mathbf{1} \cdot(\mathrm{DABCO})^{\text {in. }}$ (DABCO) ${ }^{\text {out }}$. $\mathrm{C}=$ gray, $\mathrm{H}=$ white, $\mathrm{N}=$ blue, $\mathrm{O}=$ red, $\mathrm{Zn}=$ purple, $\mathrm{Cu}=$ brown, and $\mathrm{Ni}=$ green. Substituents on the phenyl groups and solvated molecules are omitted for clarity. The bound DABCO molecules were disordered at the two sites with half occupancy, and one site is shown. For $\mathrm{Zn}^{\mathrm{Il}} \mathbf{- 1}$, two crystallographically independent but structurally similar molecules existed in the crystal, and therefore, only one molecule is shown.

Table 1. Selected structural data.

\begin{tabular}{llll}
\hline & $\mathrm{Zn}^{[e]}$ & $\mathrm{Cu}$ & $\mathrm{Ni}$ \\
\hline $\mathrm{M}-\mathrm{N}_{\mathrm{DABCO}}$ & $\begin{array}{l}2.197(2), \\
2.207(2)\end{array}$ & $2.428(2)$ & $2.411(3), 2.407(3)^{[\mathrm{f}]}$ \\
& & & \\
$\left(\mathrm{M}-\mathrm{N}_{\text {pyrrole }}\right)_{\mathrm{av}} / \AA$ & $2.062,2.064$ & 2.013 & 2.033 \\
$\mathrm{M}-\mathrm{P}_{\text {porN4 }} / \AA^{[a]}$ & $0.289,0.300$ & 0.123 & 0.007 \\
$\mathrm{M} \cdots \mathrm{M} / \AA^{[b]}$ & $\begin{array}{l}6.9723(7), \\
7.0090(5)\end{array}$ & $7.451(1)$ & $7.4486(8)$ \\
$\mathrm{P}$ & $7.553,7.608$ & 7.680 & 7.455 \\
$\mathrm{mpd} / \AA^{[d]}$ & 0.0537, & 0.0611 & 0.0803 \\
& 0.0653 & & \\
\hline
\end{tabular}

[a] The vertical distance between metal ion and the mean plane defined by four $\mathrm{N}$ atoms of the porphyrin macrocycles. [b] The intramolecular $\mathrm{M} \cdot \mathrm{M} \mathrm{M}$ distance. [c] The interplane distance between two porphyrin macrocycles. The mean plane was defined by the core 24 atoms of the porphyrin macrocycles. [d] Mean plane deviation defined by the core 24 atoms. [e] Two crystallographically independent molecules existed in the crystal, and therefore, both values are shown. [f] M-NDABCO-in and M-NDABCO-out, respectively. 
The structure of $\mathrm{Zn}^{\mathrm{Il}}-1 \cdot(\mathrm{DABCO})^{\text {in }}$ was confirmed by X-ray crystallography (Figures $1 a, b$ and S2, Tables 1 and S1). As expected, one DABCO molecule was bound in the cavity of $\mathrm{Zn}^{\prime \prime}$ 1 by axial coordination on both nitrogen atoms of the guest molecules to the zinc ions. The overall structure was relatively similar to that of 1 reported previously. ${ }^{[34]}$ The $Z n^{11}-N_{D A B C O}$ bond length was $\sim 2.20 \AA$, slightly longer than the $Z n^{\prime \prime}-\mathrm{N}_{\text {por }}$ bond length $(\sim 2.06 \AA)$. The $\mathrm{Zn}$ ions were located $0.29-0.30 \AA$ off the mean plane comprising four nitrogen atoms. Therefore, the $\mathrm{Zn}$ " ions had distorted square-pyramidal geometry. These structural features are identical to those of the reported DABCO-coordinated $\mathrm{Zn}^{\prime \prime}$ porphyrin hosts. ${ }^{[48-51]}$

To estimate the binding constants between $\mathrm{Zn}$ "-1 and DABCO $U V / v i s$ titration experiments were carried out (Figure 2). When $\mathrm{DABCO}$ is added to the solution of $\mathrm{Zn}^{\mathrm{Il}}-\mathbf{1}$ in chlorobenzene, both Soret and $Q$ bands red-shifted, indicating axial coordination of $\mathrm{DABCO}$ on the $\mathrm{Zn}$ ions of porphyrins. The end-point of the spectral change is reached when one equivalent of $D A B C O$ molecules is added to the solution of $\mathrm{Zn}^{\mathrm{N}}-1$ in chlorobenzene. However, the value of the obtained $K_{1}$ value shows a large deviation from that determined by nonlinear curve fitting $\left(K_{1}=\right.$ $7.2 \pm 17.5) \times 10^{9} \mathrm{M}^{-1}$ ), probably because it is difficult to directly determine a high binding constant $\left(>10^{8}\right)$ by UV/Vis titration. ${ }^{[7,55]}$
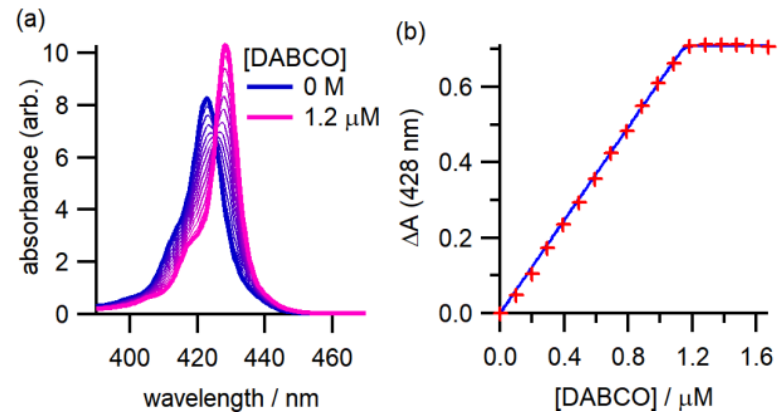

Figure 2. (a) UV/vis spectral change of the Soret band of $\mathrm{Zn}^{\mathrm{I}}-\mathbf{1}(1.15 \mu \mathrm{M})$ upon adding DABCO $(0-1.2 \mu \mathrm{M})$ in chlorobenzene at $298 \mathrm{~K}$. (b) Titration curve of $\mathrm{Zn}$ ". 1 with DABCO monitored at $429 \mathrm{~nm}$. The solid line represents the best fitting curve.

We then evaluated the guest binding behavior of $\mathrm{Cu}^{\text {II }}-\mathbf{1}$. The UV/vis titration experiment showed that $\mathrm{Cu}^{\mathrm{II}}-\mathbf{1}$ also bind DABCO to form $\mathrm{Cu}^{\prime \prime}-1 \cdot(\mathrm{DABCO})^{\text {in }}$ (Figure 3). Upon adding DABCO, both Soret and $\mathrm{Q}$ bands of $\mathrm{Cu}^{\mathrm{I}}-\mathbf{1}$ red-shifted. Similar to that of $\mathrm{Zn}^{\mathrm{N}}-\mathbf{1}$, Cull-1 shows isosbestic points, suggesting the formation of a $1: 1$ host-guest complex, Cu"-1-(DABCO) in. Binding constant $K_{1}$ was determined to be $928 \pm 10 \mathrm{M}^{-1}$ by nonlinear curve fitting.

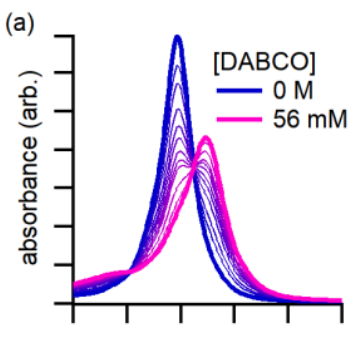

380400420440460480 wavelength / $\mathrm{nm}$

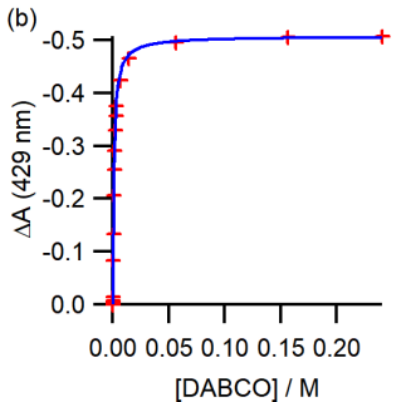

Figure 3. (a) UV/vis spectral change of the Soret band of $\mathrm{Cu}^{\mathrm{Il}}-1(1.08 \mu \mathrm{M})$ upon the addition of DABCO in chlorobenzene at $298 \mathrm{~K}$. (b) Titration curve of $\mathrm{Cu}^{\mathrm{II}}-1$ with DABCO monitored at $429 \mathrm{~nm}$. The solid line represents the best fitting curve.

The structure of $\mathrm{Cu}^{\mathrm{Il}}-\mathbf{1} \cdot(\mathrm{DABCO})^{\text {in }}$ was elucidated by X-ray crystallography (Figure 1c,d). The cavity of $\mathrm{Cu}^{\mathrm{ll}}-1$ had one DABCO molecule. The two porphyrin macrocycles retained their planarity with a small mean plane deviation $0.06 \AA$ for the 24 core atoms. The $\mathrm{Cu}-\mathrm{N}_{\mathrm{DABCO}}$ bond length was $2.428(2) \AA$, which was considerably longer than the $\mathrm{Cu}-\mathrm{N}_{\text {por }}$ bond length $(2.013 \AA$ ) $)$. Such a long bond length is characteristic of the d9 metal ion. The $\mathrm{Cu}^{\prime \prime}$ ions were located $0.12 \AA$ off the mean plane core comprising four nitrogen atoms, a shorter distance than that between $\mathrm{Zn}^{\mathrm{I}}-\mathbf{1}$ and the nitrogen atoms. Therefore, the interplane distance between two porphyrin macrocycles was relatively similar between $\mathrm{Zn}$ "-1 and $\mathrm{Cu}^{\mathrm{I}}-\mathbf{1}$ despite the different $\mathrm{M}-\mathrm{N}_{\mathrm{DABCO}}$ bond lengths.

To evaluate the structural effect of highly rigid Cu" 1 , a titration experiment was also performed on the flexible acyclic dimer Cull$2^{[34]}$ and monomer $\mathrm{Cu}^{\mathrm{II}}-3$ (Figure 4). A slight spectral change was

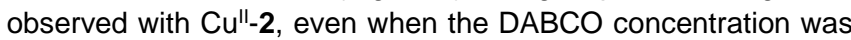
$0.5 \mathrm{M}$. No spectral change was observed when the DABCO concentration was $1.3 \mathrm{M}$. This result is acceptable considering the extremely small binding constants of Cull porphyrins. ${ }^{[14-17]}$ Hence, it can be concluded that the significant rigidity of $\mathbf{1}$ induces guest binding through cooperative effect of the weak axial ligation on Cull ions. (a)

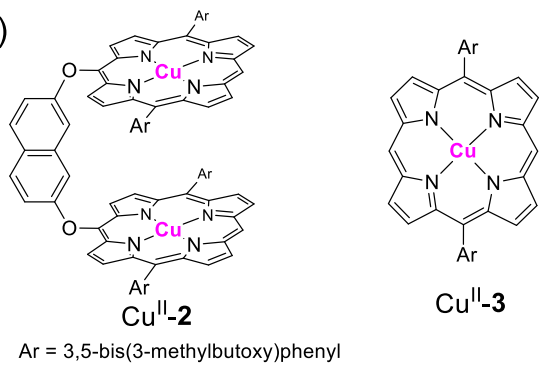

(b)

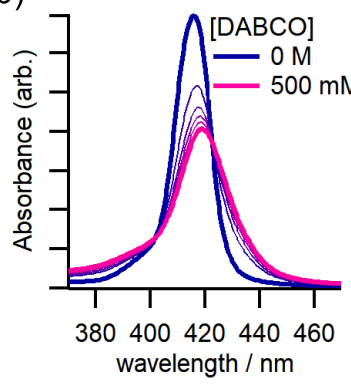

(c)

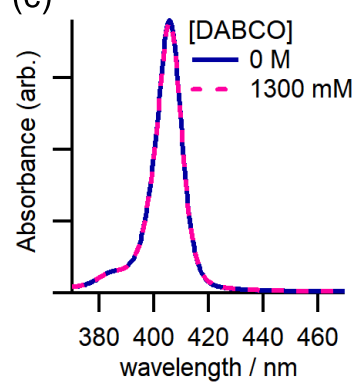

Figure 4. (a) Chemical structures of the reference compounds. UV/vis spectral change of the Soret band of (b) $\mathrm{Cu}^{\text {II-2 }}$ and (c) $\mathrm{Cu}^{\text {"l }}-3$ upon the addition of DABCO in chlorobenzene at $298 \mathrm{~K}$.

To explore the scope of this approach to induce unusual axial ligation, the binding of DABCO in the $\mathrm{Ni}^{\prime \prime}-\mathbf{1}$ complexes was evaluated. As expected, Ni"-1 exhibited the binding of DABCO molecules revealed by UV/vis titration experiments. Contrary to the spectral change in $\mathrm{Zn}^{\mathrm{N}}-\mathbf{1}$ and $\mathrm{Cu}^{\mathrm{II}}-\mathbf{1}$, that in $\mathrm{Ni}^{\mathrm{II}}-\mathbf{1}$ does not have any isosbestic points (Figure $5 \mathrm{a}$ ). This result suggests that 
more than three species are involved in the titration. Considering that Nill-porphyrins generally favor two-ligand coordination to form octahedral 6-coordinate $\mathrm{Ni}^{l l}$ species instead of one-ligand coordination, ${ }^{[13,18-23]}$ two additional DABCO molecules bind outside and one inside the cavity of $\mathrm{Ni}^{\mathrm{I}}-\mathbf{1}$ to form Nill1. $(\mathrm{DABCO})^{\text {in }}$. (DABCO) ${ }^{\text {out }} 2$ (Scheme 1).

The structure of the $\mathrm{Nill}^{\prime \prime} \mathbf{1} \cdot(\mathrm{DABCO})^{\text {in. }}$ (DABCO) ${ }^{\text {out }}{ }_{2}$ complex comprising three DABCO molecules was unambiguously determined by X-ray diffraction (Figure $1 \mathrm{e}$ and f). The Ni-N $\mathrm{N}_{\text {DABCO- }}$ in and Ni-N $\mathrm{N}_{\text {DABCO-out }}$ bond lengths were 2.411(3) and 2.407(3) $\AA$, respectively. These bond lengths were considerably longer than those of $\mathrm{Ni}-\mathrm{N}_{\text {por }}(2.033 \AA)$, and slightly longer than those of 6 coordinate octahedral Ni-porphyrinoid complexes (2.2-2.3 A). ${ }^{[19,20,22,27,28,32,56]}$ The Ni ions were located mostly on the mean plane core comprising four nitrogen atoms.

The binding constants were determined from the UV/vis titration experiment (Figure 5b). To simplify the fitting model, we postulated a single-step formation of $\mathrm{Ni}^{\prime \prime}$ 1.(DABCO $)^{\text {in. }} \cdot(\mathrm{DABCO})^{\text {out }}{ }_{2}$ from $\mathrm{Ni}^{\mathrm{ll}}-\mathbf{1} \cdot(\mathrm{DABCO})^{\text {in }}$ with one equilibrium constant $\left(K_{2}\right) . K_{1}$ and $K_{2}$ were determined to be $2.84 \pm 0.22 \mathrm{M}^{-1}$ and $132 \pm 15 \mathrm{M}^{-2}$, respectively.
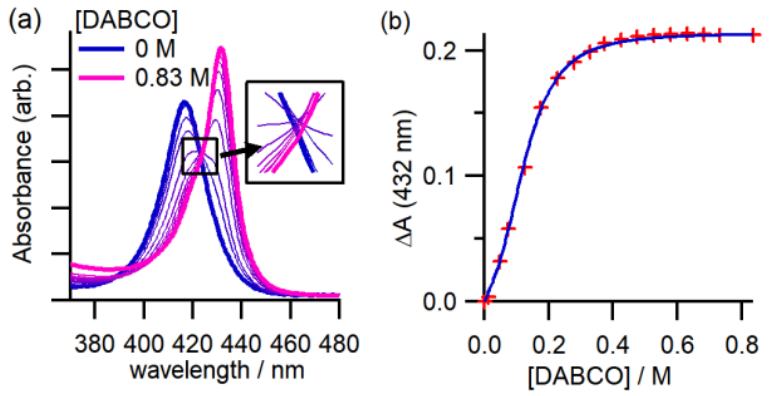

Figure 5. UV/vis spectral change of the Soret band of $\mathrm{Ni}^{\mathrm{I}}-\mathbf{1}(1.01 \mu \mathrm{M})$ upon the addition of DABCO $(0-0.83 \mathrm{M})$ in chlorobenzene at $298 \mathrm{~K}$.

Axial coordination on the $\mathrm{Ni}^{\prime \prime}$ ion in the porphyrins induces spin change from diamagnetic to paramagnetic. ${ }^{[18,22,23,28,32,56-59]}$ This phenomenon was also observed in the DABCO binding in $\mathrm{Ni}^{\mathrm{Il}}-\mathbf{1}$. While the ${ }^{1} \mathrm{H}$ NMR signals of $\beta$-protons for free $\mathrm{Ni}^{\prime \prime}-1$ was observed within the range of typical diamagnetic compounds (8.89 and $8.53 \mathrm{ppm}$ in $\mathrm{CDCl}_{3}$ ), those of $\mathrm{Ni}^{\prime \prime}-1$ in the presence of DABCO appeared significantly downfield (51.9 and $49.6 \mathrm{ppm}$ ) (Figure S11). This behavior is the characteristic of the reported 6coordinated $\mathrm{Ni}^{\prime \prime}$-porphyrins and clearly indicates the paramagnetic character of $\mathrm{Nill}^{-1} \cdot(\mathrm{DABCO})^{\text {in. }} \cdot(\mathrm{DABCO})^{\text {out }_{2} \text {. }}$

\section{Conclusion}

We demonstrated the unusual axial coordination on $\mathrm{Cu}^{\prime \prime}$ and $\mathrm{Ni}^{\prime \prime}$ ions on the cofacial cyclic porphyrin dimer. Its remarkably high rigidity enhanced its cooperative axial ligation ability. To the best of our knowledge, this is the first report on the use of Cu"- and Ni"porphyrins for coordination-induced guest binding of porphyrinbased host molecules without using other metal ions. Different metal complexes with various anomalous coordination forms, such as relatively rare 5- or 6-coordinated $\mathrm{Pd}^{\prime \prime}$ species that are difficult to prepare in solution, can be synthesized by utilizing the strategy presented herein. The syntheses of such complexes with an abnormal coordination mode and investigation of their properties are underway and the results will be reported in due time.

\section{Experimental Section}

\section{Instrumentation and Materials}

Bis(2,7-naphthylenedioxy)-bridged cyclic porphyrin dimer (1), ${ }^{[34]}$ monobridged acyclic porphyrin dimer (2), ${ }^{[34]}$ and reference monomer $(3)^{[60]}$ were synthesized as previously reported procedures. Chlorobenzene $(\mathrm{PhCl})$ was distilled from $\mathrm{CaH}_{2}$. All other chemicals were of reagent grades and used without any further purification. $\mathrm{CDCl}_{3}$ was acquired from Cambridge Isotope Laboratories, Inc. Analytical thin layer chromatography (TLC) was performed on silica gel $60 \mathrm{~F}_{254}$ plates. Flash column chromatography was performed using silica gel $60 \mathrm{~N}$ (spherical, neutral, 40-50 $\mu \mathrm{m}$ ). NMR spectral data were recorded on a JEOL ECS500 spectrometers. These data were collected at ambient temperature $\left(25^{\circ} \mathrm{C}\right) .{ }^{1} \mathrm{H}$ NMR spectra were referenced internally to tetramethylsilane as a standard. ${ }^{13} \mathrm{C}$ NMR spectra were referenced internally to a solvent signal $\left(\delta=77.0 \mathrm{ppm}\right.$ for $\left.\mathrm{CDCl}_{3}\right)$. IR measurements were recorded on a JASCO FT/IR-6100 spectrometer equipped with an ATR unit. UV/Vis spectral data were recorded on a SHIMADZU UV-3150 spectrometer.

\section{Synthesis of Zn"-1}

A mixture of $1(100.1 \mathrm{mg}, 0.0520 \mathrm{mmol})$ and $\mathrm{Zn}(\mathrm{OAc})_{2} \cdot 2 \mathrm{H}_{2} \mathrm{O}(114.5 \mathrm{mg}$ $0.522 \mathrm{mmol})$ in $\mathrm{CHCl}_{3}(6 \mathrm{~mL})$ and $\mathrm{MeOH}(0.6 \mathrm{~mL})$ was stirred at room temperature for $2 \mathrm{~h}$. The reaction mixture was directly poured on top of a basic alumina column packed with $\mathrm{CHCl}_{3}$, then eluted with $\mathrm{CHCl}_{3}$. The solvent was removed under reduced pressure to give $\mathrm{Zn}^{\text {"l}}-1$ as purple powder (100.4 mg, $0.0489 \mathrm{mmol}, 94 \%)$. Analytically pure product was obtained by the recrystallization from hot toluene-hexane. $R_{\mathrm{f}}=0.37$ (silica gel, hexane/toluene $=1: 3)$; m.p. $>300{ }^{\circ} \mathrm{C} ;{ }^{1} \mathrm{H}$ NMR $\left(500 \mathrm{MHz}, \mathrm{CDCl}_{3}\right) \delta=$ $9.00(\mathrm{~d}, J=4.6 \mathrm{~Hz}, 8 \mathrm{H}), 8.68(\mathrm{~d}, J=4.2 \mathrm{~Hz}, 8 \mathrm{H}), 8.03(\mathrm{~d}, J=8.8 \mathrm{~Hz}, 4 \mathrm{H})$, 7.92 (dd, $J=9.4,2.5 \mathrm{~Hz}, 4 \mathrm{H}$ ), 7.11 (t, $J=1.5 \mathrm{~Hz}, 4 \mathrm{H}$ ), 6.85 (t, $J=1.5 \mathrm{~Hz}$, $4 \mathrm{H}), 6.74(\mathrm{t}, J=2.3 \mathrm{~Hz}, 4 \mathrm{H}), 4.41(\mathrm{~d}, J=2.7 \mathrm{~Hz}, 4 \mathrm{H}), 4.01-3.96(\mathrm{~m}, 16 \mathrm{H})$ 1.87-1.72 (m, 16H), $1.64(\mathrm{q}, J=6.8 \mathrm{~Hz}, 8 \mathrm{H}), 1.01(\mathrm{~d}, J=6.9 \mathrm{~Hz}, 24 \mathrm{H})$, $0.88 \mathrm{ppm}(\mathrm{d}, J=6.5 \mathrm{~Hz}, 24 \mathrm{H}) ;{ }^{13} \mathrm{C} \mathrm{NMR}\left(125 \mathrm{MHz}, \mathrm{CDCl}_{3}\right) \delta=164.9(\mathrm{Cq})$, $158.4(\mathrm{Cq}), 157.7(\mathrm{Cq}), 149.2(\mathrm{Cq}), 145.7(\mathrm{Cq}), 143.1(\mathrm{Cq}), 134.8(\mathrm{Cq})$, $132.5(\mathrm{CH}), 131.4(\mathrm{Cq}), 129.3(\mathrm{CH}), 127.3(\mathrm{CH}), 124.6(\mathrm{Cq}), 120.8(\mathrm{Cq})$, $116.2(\mathrm{CH}), 115.0(\mathrm{CH}), 113.8(\mathrm{CH}), 111.2(\mathrm{CH}), 101.0(\mathrm{CH}), 66.8\left(\mathrm{CH}_{2}\right)$, 66.6 $\left(\mathrm{CH}_{2}\right), 38.1\left(\mathrm{CH}_{2}\right), 37.8\left(\mathrm{CH}_{2}\right), 25.2(\mathrm{CH}), 24.9(\mathrm{CH}), 22.9\left(\mathrm{CH}_{3}\right), 22.5$ ppm $\left(\mathrm{CH}_{3}\right)$; IR (ATR): v $=2952,2867,2365,1629,1586,1511,1430$, $1384,1350,1328,1183,1155,1031,1002,941,866,831,794,718 \mathrm{~cm}^{-1}$ UV/Vis (chlorobenzene): $\lambda_{\max }(\log \varepsilon)=423$ (5.91), 517 (3.76), 553.5 (4.53), $596 \mathrm{~nm}$ (3.99); elemental analysis calcd (\%) for $\mathrm{C}_{124} \mathrm{H}_{128} \mathrm{~N}_{8} \mathrm{O}_{12} \mathrm{Zn}_{2}$ : C, 72.54; H, 6.28; N, 5.46; found: C, 72.23; H, 6.20; N, 5.38 .

\section{Synthesis of Cu"-1}

A mixture of $1(31.6 \mathrm{mg}, 0.0164 \mathrm{mmol})$ and $\mathrm{Cu}(\mathrm{OAc})_{2} \cdot \mathrm{H}_{2} \mathrm{O}(33.6 \mathrm{mg}, 0.168$ $\mathrm{mmol})$ in $\mathrm{CHCl}_{3}(2 \mathrm{~mL})$ and $\mathrm{MeOH}(0.2 \mathrm{~mL})$ was stirred at room temperature for $0.5 \mathrm{~h}$. The reaction mixture was directly poured on top of a silica gel column packed with $\mathrm{CHCl}_{3}$, then eluted with $\mathrm{CHCl}_{3}$. The solvent was removed under reduced pressure to give Cull-1 as reddish purple powder (32.6 mg, $0.0159 \mathrm{mmol}, 97 \%$ ). Analytically pure product was obtained by the recrystallization from hot toluene-hexane. $R_{\mathrm{f}}=0.20$ (silica gel, hexane/ $\mathrm{CHCl}_{3}=3: 2$ ); $\mathrm{m}$.p. $>300{ }^{\circ} \mathrm{C}$; IR (ATR): $v^{\sim}=2952,2868,2364$ $1630,1587,1512,1451,1432,1383,1354,1336,1245,1222,1187,1161$, 1064, 1006, 866, 831, 795, $716 \mathrm{~cm}^{-1}$; UV/Vis (chlorobenzene): $\lambda_{\max }(\log \varepsilon)$ $=417$ (5.63), $531 \mathrm{~nm}$ (4.50); elemental analysis calcd (\%) for $\mathrm{C}_{124} \mathrm{H}_{128} \mathrm{~N}_{8} \mathrm{O}_{12} \mathrm{Cu}_{2}$ : C, 72.67; H, 6.30; N, 5.47; found: C, 72.42; H, 6.20; N, 5.46 . 


\section{Synthesis of $\mathrm{Ni}^{\mathrm{l}}-1$}

A mixture of $1(53.0 \mathrm{mg}, 0.0275 \mathrm{mmol})$ and $\mathrm{Ni}(\mathrm{acac})_{2}$ (1133.3 mg, 0.556 $\mathrm{mmol})$ in toluene $(6 \mathrm{~mL})$ was refluxed for $16 \mathrm{~h}$. The reaction mixture was directly poured on top of a silica gel column packed with $\mathrm{CHCl}_{3}$, then eluted with $\mathrm{CHCl}_{3}$. The solvent was removed under reduced pressure to give $\mathrm{Nill}_{-}$ 1 as reddish purple powder (54.3 mg, $0.0266 \mathrm{mmol}, 97 \%$ ). Analytically pure product was obtained by the recrystallization from hot toluenehexane. $R_{\mathrm{f}}=0.74$ (silica gel, hexane/ $\mathrm{CH}_{2} \mathrm{Cl}_{2}=1: 2$ ); m.p. $>300{ }^{\circ} \mathrm{C} ;{ }^{1} \mathrm{H}$ NMR $\left(400 \mathrm{MHz}, \mathrm{CDCl}_{3}\right) \delta=8.89(\mathrm{~d}, J=4.9 \mathrm{~Hz}, 8 \mathrm{H}), 8.53(\mathrm{~d}, J=4.9 \mathrm{~Hz}, 8 \mathrm{H})$, 8.01 (d, $J=9.0 \mathrm{~Hz}, 4 \mathrm{H}$ ), 7.86 (dd, $J=9.2,2.4 \mathrm{~Hz}, 4 \mathrm{H}$ ), 7.20 (brs, 4H), 6.69 (t, $J=2.2 \mathrm{~Hz}, 4 \mathrm{H}), 6.52$ (brs, 4H), $4.88(\mathrm{~d}, J=2.4 \mathrm{~Hz}, 4 \mathrm{H}$ ), 4.01 (t, $J=6.5$ $\mathrm{Hz}, 8 \mathrm{H}), 3.89(\mathrm{t}, J=6.6 \mathrm{~Hz}, 8 \mathrm{H}), 1.89-1.79(\mathrm{~m}, 4 \mathrm{H}), 1.76-1.70(\mathrm{~m}, 12 \mathrm{H})$, 1.59 (q, $J=6.5 \mathrm{~Hz}, 8 \mathrm{H}), 0.99(\mathrm{~d}, J=6.4 \mathrm{~Hz}, 24 \mathrm{H}), 0.85 \mathrm{ppm}(\mathrm{d}, J=6.4 \mathrm{~Hz}$, $24 \mathrm{H}) ;{ }^{13} \mathrm{C} \mathrm{NMR}\left(125 \mathrm{MHz}, \mathrm{CDCl}_{3}\right) \delta=163.0(\mathrm{Cq}), 158.6(\mathrm{Cq}), 158.1(\mathrm{Cq})$ $142.5(\mathrm{Cq}), 142.0(\mathrm{Cq}), 139.3(\mathrm{Cq}), 134.8(\mathrm{Cq}), 132.4(\mathrm{CH}), 130.7(\mathrm{Cq})$, $129.6(\mathrm{CH}), 127.2(\mathrm{CH}), 124.9(\mathrm{Cq}), 119.3(\mathrm{Cq}), 116.4(\mathrm{CH}), 113.3(\mathrm{CH})$ $110.6(\mathrm{CH}), 101.0(\mathrm{CH}), 66.7\left(\mathrm{CH}_{2}\right), 66.5\left(\mathrm{CH}_{2}\right), 38.1\left(\mathrm{CH}_{2}\right), 37.9\left(\mathrm{CH}_{2}\right)$, $25.2(\mathrm{CH}), 24.9(\mathrm{CH}), 22.7\left(\mathrm{CH}_{3}\right), 22.5 \mathrm{ppm}\left(\mathrm{CH}_{3}\right)$; IR (ATR): v = 2926 2869, 2363, 1631, 1587, 1464, 1450, 1346, 1313, 1247, 1124, 1120,1165, 1135, 1065, 1010, 971, 956, 866, 830, 822, 795, 771, 722, $694 \mathrm{~cm}^{-1}$ UV/Vis (chlorobenzene): $\lambda_{\max }(\log \varepsilon)=417$ (5.63), $531 \mathrm{~nm}$ (4.50); MS(MALDI-TOF): $\mathrm{m} / \mathrm{z} 1762.98\left([\mathrm{M}+\mathrm{H}]^{+}\right)$; elemental analysis calcd $(\%)$ for $\mathrm{C}_{124} \mathrm{H}_{128} \mathrm{~N}_{8} \mathrm{O}_{12} \mathrm{Ni}_{2}$ : C, 73.01; $\mathrm{H}, 6.33 ; \mathrm{N}, 5.49$; found: C, 72.85; H, 6.20; N, 5.52 .

\section{Synthesis of $\mathrm{Cu}^{\mathrm{I}}-2$}

Cu"-2 was synthesized in a similar manner to that of $\mathbf{C u}^{\text {"l-1. }}$. Analytically pure product was obtained by the recrystallization from hot ethyl acetate. UV/Vis (chlorobenzene): $\lambda_{\max }=416,536 \mathrm{~nm}$; elemental analysis calcd $(\%)$ for $\mathrm{C}_{114} \mathrm{H}_{124} \mathrm{~N}_{8} \mathrm{O}_{10} \mathrm{Cu}_{2} \cdot(\mathrm{EtOAc})$ : $\mathrm{C}, 71.53 ; \mathrm{H}, 6.71 ; \mathrm{N}, 5.66$; found: $\mathrm{C}, 71.41$ $\mathrm{H}, 6.59 ; \mathrm{N}, 5.96$

\section{Synthesis of Cull-3}

$\mathrm{Cu}^{\text {II-3 }}$ was synthesized in a similar manner to that of $\mathbf{C u}^{\mathrm{II}}-\mathbf{1}$. Analytically pure product was obtained by the recrystallization from $\mathrm{CH}_{2} \mathrm{Cl}_{2}-$ methanol. UV/Vis (chlorobenzene): $\lambda_{\max }=405.5,528,562 \mathrm{~nm}$; elemental analysis calcd (\%) for $\mathrm{C}_{52} \mathrm{H}_{60} \mathrm{~N}_{4} \mathrm{O}_{4} \mathrm{Cu}$ : C, 71.90; $\mathrm{H}, 6.96 ; \mathrm{N}, 6.45$; found: $\mathrm{C}, 71.77$; $\mathrm{H}, 6.99 ; \mathrm{N}, 6.42$.

\section{X-Ray crystal structure determinations}

Single crystals of $\left[\mathrm{Zn}^{\mathrm{I}}-\mathbf{1} \cdot(\mathrm{DABCO})^{i n}\right] \cdot\left(\mathrm{o}-\mathrm{C}_{6} \mathrm{H}_{4} \mathrm{Cl}_{2}\right)_{2}$ were obtained by the slow diffusion of methanol vapor into their solution in o-dichlorobenzene. Single crystals of $\left[\mathrm{Cu}^{\mathrm{ll}}-\mathbf{1} \cdot(\mathrm{DABCO})^{i m}\right] \cdot(\mathrm{DABCO}) \cdot\left(\mathrm{CH}_{3} \mathrm{CN}\right)_{2}$ were obtained by layering of a o-dichlorobenzene solution of $\mathrm{Cu}^{\mathrm{Il}}-1$ and $\mathrm{DABCO}$ (excess) with a saturated acetonitrile solution of DABCO. Single crystals of [Nill1. (DABCO $\left.)^{\text {in }} \cdot(\mathrm{DABCO})^{\text {out }}{ }_{2}\right] \cdot\left(\mathrm{C}_{6} \mathrm{H}_{5} \mathrm{Cl}\right)_{2} \cdot\left(\mathrm{H}_{2} \mathrm{O}\right)_{2}$ were obtained by the slow diffusion of methanol vapor into a chlorobenzene solution of $\mathrm{Ni}^{\mathrm{l}}-\mathbf{1}$ and DABCO (excess).

Single-crystal X-ray diffraction data were collected on a Rigaku XtaLAB Synergy Custom diffractometer using multilayer mirror monochromated Mo-Ka radiation $(\lambda=0.71075 \AA)$ by the $\omega$ scan mode. The crystal was cooled by a stream of cold $\mathrm{N}_{2}$ gas. Collection, indexing, peak integration, cell refinement, and scaling of the diffraction data were performed using CrysAlisPro 1.171.40.75a software (Rigaku OD, 2020). The data were corrected for Lorentz and polarization effects, and empirical absorption correction was applied. The structures were solved using SHELXT[61] programs and refined by full-matrix least-squares calculations on $F^{2}$ (SHELXL). ${ }^{[62]}$ All non-hydrogen atoms were modeled anisotropically. All hydrogen atoms were placed in idealized positions and refined using a riding model $\left[U_{\text {iso }}(\mathrm{H})=1.2 U_{\text {eq }}(\mathrm{C})\right]$.
The crystallographic data are summarized in Table S1. CCDC 2045500 (Zn), $2045501(\mathrm{Cu})$, and 2045502 (Ni) contain the supplementary crystallographic data for this paper. The data can be obtained free of charge via www.ccdc.cam.ac.uk/data_request/cif.

\section{Determination of binding constants}

$3 \mathrm{~mL}$ of the M-1 solution was placed in a $1-\mathrm{cm}$ quartz cell, and $3 \mu \mathrm{L}$ of a chlorobenzene solution of DABCO was added to it using a micro-syringe. The resulting solution was stirred for $3 \mathrm{~min}$ at room temperature. Its UV/vis spectra were recorded at room temperature after each addition. The changes in absorption $(\Delta A)$ at $428 \mathrm{~nm}$ (for $\left.\mathrm{Zn}^{\prime \prime}\right), 429 \mathrm{~nm}$ (for $\left.\mathrm{Cu}^{\prime \prime}\right)$, and 432 $\mathrm{nm}$ (for $\mathrm{Ni}{ }^{\prime \prime}$ ) as a function of the concentration of the guest molecules were plotted. The binding constants (see Scheme 1) were determined by a nonlinear curve fitting based on the following equation.

$$
\begin{aligned}
& \Delta A=\frac{\left(A_{\infty}-A_{0}\right)\left([G]+[H]+K^{-1}-\sqrt{\left([G]+[H]+K^{-1}\right)^{2}-4[H][G]}\right)}{2[H]} \text { (for } \mathrm{Zn}^{\prime \prime} \text { and } \mathrm{Cu}^{\prime \prime} \text { ) } \\
& \Delta A=\frac{\left(A_{\infty}-A_{0}\right)\left(K_{1}[G]_{0}+K_{1} K_{2}[G]_{0}{ }^{3}\right)}{1+K_{1}[G]_{0}+K_{1} K_{2}[G]_{0}{ }^{3}}\left(\text { for } \mathrm{Ni}^{\prime \prime}\right)
\end{aligned}
$$

where $\Delta A$ is the differential absorbance $\left(A-A_{0}\right), A_{0}$ is the absorbance of the initial solution, $A_{\infty}$ is the absorbance of the final solution, [G]0 (= $[G]_{\text {free }}[\mathrm{G}]_{\text {bound }}$ ) is the total concentration of the guest molecule (DABCO) in the solution, and $[\mathrm{H}]_{0}\left(=[\mathrm{H}]_{\text {free }}+[\mathrm{H}]_{\text {bound }}\right)$ is the total concentration of the host molecule in the solution. In the equation for $\mathrm{Ni}^{\prime \prime}$, the same molar extinction coefficient between 5-coordinate and 6-coordinate complexes was assumed as these complexes were similar to other $\mathrm{Ni}^{\mathrm{il}}$-porphyrin analogs. ${ }^{[21,22,32] ~ W e ~ a l s o ~ a s s u m e d ~ t h a t ~ t h e ~ s y n t h e s i s ~ o f ~} \mathrm{Ni}^{\prime \prime}$ 1.(DABCO $)^{\text {in. }} \cdot(\mathrm{DABCO})^{\text {out }}{ }_{2}$ from $\mathrm{Ni}^{\mathrm{ll}}-\mathbf{1} \cdot(\mathrm{DABCO})^{\text {in }}$ involved only one step with one equilibrium constant $\left(K_{2}\right)$.

\section{Acknowledgements}

This work was supported by JSPS KAKENHI Grant Numbers JP17K14447 and JP25110002. The NMR, and X-ray diffraction measurements were performed at the Analytical Instrument Facility, Graduate School of Science, Osaka University.

Keywords: Cooperative effects $\cdot$ Coordination modes $\cdot$ Hostguest systems $\bullet$ Molecular recognition $\bullet$ Porphyrinoids

[1] J. K. Sanders, N. Bampos, Z. Clyde-Watson, S. L. Darling, J. C Hawley, H. J. Kim, C. C. Mak, S. J. Webb, in Porphyr. Handbook, Vol. 3 (Eds.: K.M. Kadish, K.M. Smith, R. Guilard), Academic Press, San Diego, 2000, pp. 1-48.

[2] S. Durot, J. Taesch, V. Heitz, Chem. Rev. 2014, 114, 8542-8578.

[3] V. Valderrey, G. Aragay, P. Ballester, Coord. Chem. Rev. 2014, 258-259, 137-156

[4] Y. Nakamura, N. Aratani, A. Osuka, Chem. Soc. Rev. 2007, 36 831-845.

[5] T. Y. Cen, S. P. Wang, Z. Zhang, J. Wu, S. Li, J. Porphyrins Phthalocyanines 2018, 22, 726-738.

[6] S.-P. Wang, Y.-F. Shen, B.-Y. Zhu, J. Wu, S. Li, Chem. Commun 2016, 52, 10205-10216.

[7] M. Hoffmann, C. J. Wilson, B. Odell, H. L. Anderson, Angew. Chem Int. Ed. 2007, 46, 3122-3125.

[8] M. Hoffmann, J. Kärnbratt, M.-H. Chang, L. M. Herz, B. Albinsson, H. L. Anderson, Angew. Chem. Int. Ed. 2008, 47, 4993-4996. J. K. Sprafke, D. V Kondratuk, M. Wykes, A. L. Thompson, M. Hoffmann, R. Drevinskas, W.-H. Chen, C. K. Yong, J. Kärnbratt, J. E. Bullock, M. Malfois, M. R. Wasielewski, B. Albinsson, L. M. Herz, D. Zigmantas, D. Beljonne, H. L. Anderson, J. Am. Chem. Soc. 2011, 133, 17262-17273.

[10] M. C. O'Sullivan, J. K. Sprafke, D. V. Kondratuk, C. Rinfray, T. D. W. Claridge, A Saywell, M. O. Blunt, J. N. O'Shea, P. H. Beton, M. Malfois, H. L. Anderson, Nature 2011, 469, 72-75.

[11] M. Tabata, J. Nishimoto, in Porphyr. Handbook, Vol. 9 (Eds.: K.M. Kadish, K.M. Smith, R. Guilard), Academic Press, San Diego, 2000 pp. 221-419.

[12] P. Hambright, Chem. Commun. 1967, 470-471. 
F. A. Walker, E. Hui, J. M. Walker, J. Am. Chem. Soc. 1975, 97, 2390-2397.

J. R. Miller, G. D. Dorough, J. Am. Chem. Soc. 1952, 74, 39773981.

G. Szintay, A. Horváth, G. Grampp, J. Photochem. Photobiol. A Chem. 1999, 126, 83-89.

G. Szintay, A. Horváth, Inorganica Chim. Acta 2001, 324, 278-285. J. Cremers, S. Richert, D. V. Kondratuk, T. D. W. Claridge, C. R. Timmel, H. L. Anderson, Chem. Sci. 2016, 7, 6961-6968.

T. La, R. A. Richards, R. S. Lu, R. Bau, G. M. Miskelly, Inorg. Chem. 1995, 34, 5632-5640.

S.-L. Jia, W. Jentzen, M. Shang, X.-Z. Song, J.-G. Ma, W. R. Scheidt, J. A. Shelnutt, Inorg. Chem. 1998, 37, 4402-4412. H. Duval, V. Bulach, J. Fischer, R. Weiss, Inorg. Chem. 1999, 38, 5495-5501.

Y. Song, R. E. Haddad, S. L. Jia, S. Hok, M. M. Olmstead, D. J. Nurco, N. E. Schore, J. Zhang, J. G. Ma, K. M. Smith, S. Gazeau, J. Pécaut, J. C. Marchon, C. J. Medforth, J. A. Shelnutt, J. Am. Chem. Soc. 2005, 127, 1179-1192.

S. Thies, C. Bornholdt, F. Köhler, F. D. Sönnichsen, C. Näther, F. Tuczek, R. Herges, S. I. Materials, A. Fluor-, S.- Aldrich, D. Core, Chem. - Eur. J. 2010, 16, 10074-10083.

M. Dommaschk, F. Gutzeit, S. Boretius, R. Haag, R. Herges, Chem. Commun. 2014, 50, 12476-12478.

T. Kaufmann, B. Shamsai, R. S. Lu, R. Bau, G. M. Miskelly, Inorg. Chem. 1995, 34, 5073-5079.

A. A. Sinelshchikova, S. E. Nefedov, Y. Y. Enakieva, Y. G.

Gorbunova, A. Y. Tsivadze, K. M. Kadish, P. Chen, A.

Bessmertnykh-Lemeune, C. Stern, R. Guilard, Inorg. Chem. 2013, 52, 999-1008.

M. Amati, E. J. Baerends, G. Ricciardi, A. Rosa, Inorg. Chem. 2020, 59, 11528-11541.

M. Dommaschk, V. Thoms, C. Schütt, C. Näther, R. Puttreddy, K. Rissanen, R. Herges, Inorg. Chem. 2015, 54, 9390-9392.

A. Yagi, T. Kondo, D. Yamashita, N. Wachi, H. Omori, N. Fukui, T. Ikeue, H. Shinokubo, Chem. - A Eur. J. 2019, 25, 15580-15585.

D. W. J. McCallien, J. K. M. Sanders, J. Am. Chem. Soc. 1995, 117 6611-6612.

A. L. Balch, M. M. Olmstead, S. L. Phillips, Inorg. Chem. 1993, 32, 3931-3936.

A. L. Balch, B. C. Noll, S. L. Phillips, S. M. Reid, E. P. Zovinka, Inorg. Chem. 1993, 32, 4730-4736.

K. Yamashita, D. Hirano, K. Sugiura, Eur. J. Inorg. Chem. 2020, 2020, 3507-3516.

S. Richert, J. Cremers, I. Kuprov, M. D. Peeks, H. L. Anderson, C. R. Timmel, Nat. Commun. 2017, 8, 14842 .

K. Yamashita, N. Kuramochi, H. Pham Qui Van, K. Furutani, T. Ogawa, K. Sugiura, Chempluschem 2020, 85, 217-226.

K. Yamashita, K. Kataoka, M. S. Asano, K. Sugiura, Org. Lett. 2012 14, 190-193.

K. Yamashita, S. Sakamoto, A. Suzuki, K. Sugiura, Chem. - Asian J. 2016, 11, 1004-1007.

K. Yamashita, K. Kataoka, S. Takeuchi, K. Sugiura, J. Org. Chem. 2016, 81, 11176-11184.

K. Yamashita, K. Kataoka, H. Pham Qui Van, T. Ogawa, K. Sugiura, Asian J. Org. Chem. 2018, 7, 2468-2478.

L. C. Gong, D. Dolphin, Can. J. Chem. 1985, 63, 406-411.

M. J. Crossley, L. G. King, S. M. Pyke, Tetrahedron 1987, 43, 45694577.

M. J. Crossley, L. G. King, S. M. Pyke, C. W. Tansey, J. Porphyrins Phthalocyanines 2002, 6, 685-694.

M. C. Balaban, C. Chappaz-Gillot, G. Canard, O. Fuhr, C. Roussel, T. S. Balaban, Tetrahedron 2009, 65, 3733-3739.

A. A. Ryan, S. Plunkett, A. Casey, T. McCabe, M. O. Senge, Chem. Commun. 2014, 50, 353-355.

C. H. Devillers, S. Hebié, D. Lucas, H. Cattey, S. Clément, S. Richeter, J. Org. Chem. 2014, 79, 6424-6434.

Q. Chen, Y.-Z. Zhu, Q.-J. Fan, S.-C. Zhang, J.-Y. Zheng, Org. Lett. 2014, 16, 1590-1593.

K. P. Birin, Y. G. Gorbunova, A. Y. Tsivadze, A. G. BessmertnykhLemeune, R. Guilard, Eur. J. Org. Chem. 2015, 2015, 5610-5619. M. Kielmann, K. J. Flanagan, K. Norvaiša, D. Intrieri, M. O. Senge, J. Org. Chem. 2017, 82, 5122-5134.

L. Schoepff, L. Kocher, S. Durot, V. Heitz, J. Org. Chem. 2017, 82 5845-5851.

A. L. Kieran, A. D. Bond, A. M. Belenguer, J. K. M. Sanders, Chem. Commun. 2003, 2674-2675.

H. Ding, X. Meng, X. Cui, Y. Yang, T. Zhou, C. Wang, M. Zeller, C. Wang, Chem. Commun. 2014, 50, 11162-11164.

S. Nasri, I. Zahou, I. Turowska-Tyrk, T. Roisnel, F. Loiseau, E. Saint-Amant, H. Nasri, Eur. J. Inorg. Chem. 2016, 2016, 50045019.

S. K. Samanta, D. Samanta, J. W. Bats, M. Schmittel, J. Org. Chem. 2011, 76, 7466-7473.

C. Cao, Z. Zhou, Z. Yin, Q. Liu, Org. Lett. 2009, 11, 1781-1784.
[54] J. Taesch, V. Heitz, F. Topić, K. Rissanen, Chem. Commun. 2012, $48,5118-5120$.

[55] K. Hirose, J. Inclusion Phenom. Macrocyclic Chem. 2001, 39, 193209.

[56] Y. Ide, T. Kuwahara, S. Takeshita, R. Fujishiro, M. Suzuki, S. Mori, H. Shinokubo, M. Nakamura, K. Yoshino, T. Ikeue, J. Inorg. Biochem. 2018, 178, 115-124.

[57] F. A. Walker, in Handbook of Porphyrin Science, Vol. 6 (Eds.: K.M. Kadish, K.M. Smith, R. Guilard), World Scientific Publishing, Singapore, 2010, pp. 1-337.

[58] S. Thies, H. Sell, C. Bornholdt, C. Schütt, F. Köhler, F. Tuczek, R. Herges, Chem. - Eur. J. 2012, 18, 16358-16368.

[59] M. Dommaschk, C. Schütt, S. Venkataramani, U. Jana, C. Näther, F. D. Sönnichsen, R. Herges, Dalton Trans. 2014, 43, 1739517405.

[60] M. Kawao, H. Ozawa, H. Tanaka, T. Ogawa, Thin Solid Films 2006 499, 23-28.

[61] G. M. Sheldrick, Acta Crystallogr. Sect. A Found. Adv. 2015, 71, 38.

[62] G. M. Sheldrick, Acta Crystallogr. Sect. C Struct. Chem. 2015, 71, 3-8. 


\section{Entry for the Table of Contents}

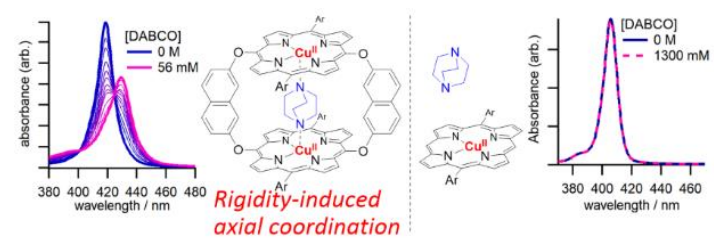

The unusual axial coordination on $\mathrm{Cu}^{\prime \prime}$ and $\mathrm{Nil}$ ions in the cofacial cyclic porphyrin dimer was induced by its remarkably high structural rigidity without the assistance of electron-withdrawing substituents or strongly coordinating metal ions such as $\mathrm{Zn}$ porphyrins. 